\title{
Research Paper: Sleep Quality in Burn Patients After Hospital Discharge
}

\author{
Roghaye Samimi ${ }^{1}$ (D), Mahnaz Shoghi ${ }^{* *}$ (D)
}

1. Shahid Motahari Burn Hospital, Iran University of Medical Sciences, Tehran, Iran.

2. Nursing Care Research Center, School of Nursing and Midwifery, Iran University of Medical Sciences, Tehran, Iran.

\begin{tabular}{|l|l|}
\hline $\begin{array}{l}\text { Use yourdevice toscan } \\
\text { and read the article online }\end{array}$ & $\begin{array}{l}\text { Crtation: Samimi, R. \& Shoghi, M., 2018. Sleep Quality in Burn Patients After Hospital Discharge. Journal of Client-Cen- } \\
\text { tered Nursing Care, 4(2), pp. 112-121. https://doi.org/10.32598/jccnc.4.2.112 }\end{array}$ \\
dol: $:$ https://doi.org/10.32598/jecnc.4.2.112
\end{tabular}

\section{(c) (1) $\Theta$}

Funding: See Page 119

Article info:

Received: 23 Oct 2017

Accepted: 10 Feb 2018

Published: 01 May 2018

Keywords:

Chronic burn, Burn injury, Sleep disorder, Sleep quality

\begin{abstract}
A B S T RA C T
Background: Sleep, as a reversible phenomenon, is vital for maintaining energy and enhancing the quality of life. Sleep disorders after burn accidents may have biopsychological effects on burn patients, years after the initial injury. This study evaluated the quality of sleep in patients with chronic burns.

Methods: A descriptive cross-sectional study was conducted on 100 patients referred to the Subspecialty Hospital for Burns in Tehran, Iran 6 months after their discharge for reconstructive surgery. Pittsburgh Sleep Quality Index was used to collect the study data. The participants were recruited by convenience sampling method. The obtained data were analyzed by Chi-square test using SPSS.

Results: According to the results, $38 \%$ of the participants had experienced good sleep quality (Mean \pm SD: $3.3 \pm 0.9$ ), but $62 \%$ reported poor sleep quality (Mean \pm SD: $9.96 \pm 3.2$ ). There were statistically significant associations between sleep quality and gender $(\mathrm{P}=0.039)$, material status ( $\mathrm{P}=0.003)$, occupational status $(\mathrm{P}=0.000)$, educational level $(\mathrm{P}=0.04)$, burn surface $(\mathrm{P}=0.02)$, and duration after burn $(\mathrm{P}=0.028)$. No statistically significant association was found between sleep quality and patients' age, burn surface, and monthly income.
\end{abstract}

Conclusion: Evaluation of sleep adequacy should be a routine component of outpatient assessment in patients with burn, with the consideration of referral to a sleep specialist, as needed.

\section{* Corresponding Author:}

Mahnaz Shoghi, PhD.

Address: Nursing Care Research Center, School of Nursing and Midwifery, Iran University of Medical Sciences, Tehran, Iran.

Tel: +98 (912) 3176343

E-mail: shoghi.m@iums.ac.ir 


\section{Highlights}

- Majority of burn patients had sleep disorders after discharge.

- Frequent nighttime awakenings, sleep latency, and sleepiness during the day were the most common sleep disorders.

- Sleep quality is associated with gender, educational level, marital status, and burn area

\section{Plain Language Summary}

Sleep problems are common after burn injury and during the healing and recovery periods. Insomnia can come and go over the years and may require different solutions at different times. It is important to get treatment for poor sleep because it can be harmful in a number of ways. For some, it can even be extremely distressing and debilitating, and actually interfere with patient's recovery from the burn injury.

\section{Background}

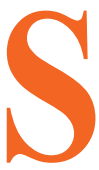

leep disorders are among the complications that hinder the healing process of burn patients (Boeve et al. 2002; Smith et al. 2008). Sleep disorder complicates the healing process and makes the burn patients more distressed. Physiological pain resulting from tissue damage (Richardson \& Mustard 2009; Carter, Carrougher \& Pham 2016), dressing change, prescribed medicines (Van der Does 1989; Seyyed-Rasooli et al. 2016), itching (Matheson, Clayton \& Muller 2001), and stress and anxiety caused by changes in appearance and uncertainty of treatment outcome and being hospitalized in the ICU can lead to sleep disorders in patients with acute burns and in the initial stages of their treatments (Giannoni-Pastor et al. 2016; Berg et al. 2017).

Sleep problems in patients in the initial phase of burn injuries have drawn much attention, and measures have been taken to resolve the problem of sleep deprivation in these patients (Yangzom et al. 2015; Bayuo, Agbenorku \& Amankwa 2016). However, burn patients' continued sleep disorders after hospital discharge is usually disregarded by the medical staff, in spite of knowing that long-lasting complications of sleep disturbances in these patients may cause further problems in the long run (Wiechman, Kalpakjian \& Johnson 2016; Vetrichevvel et al. 2016).

There is a reciprocal relationship between sleep, and physical and mental health conditions (Yangzom et al. 2015; Itani et al. 2017). Sleep deprivation can lead to the loss of concentration and (Devita et al. 2017) appetite (McNeil et al. 2016), physical and mental fatigue (Chatburn et al. 2017; Legault et al. 2017), nervous and bio-behavioral changes (Jeddi et al. 2016; Kheyri, Bas- tani \& Haghani 2016), slower information processing speed (Yarnell \& Deuster 2016), and increased accidents (Wheaton et al. 2016; Kim et al. 2015).

It can also cause depression, anxiety, lower level of consciousness (Asghari et al. 2012; Shanahan et al. 2014), reduced immune system activity (Cuesta et al. 2016; Cooper 2016), decreased glucose tolerance (Polak, Beamer \& Punjabi 2016), increased blood pressure (Peppard et al. 2000; Marin et al. 2012), greater risk for cardiovascular diseases (Kendzerska et al. 2014; Grandner et al. 2012), and poor quality of life (Ohayon, Reynolds \& Dauvilliers 2013; Reimer \& Flemons 2003). Insomnia is the most common problem in physically ill people. Such patients often complain of difficulty falling asleep, staying asleep, as well as sleep deprivation (for at least one month) that results in clinical manifestations or disrupted social or occupational functioning (Ohayon 2005; Leger 2016; Tang et al. 2014).

Research has indicated that patients with chronic burns have lower psychosocial quality of life. In other words, burn patients cannot adapt to their new conditions and changes caused by burns, which can have adverse effects on the quality of their social lives (Gauffin et al. 2016). However, sleep disorders in burn patients after hospital discharge have not attracted the due attention from researchers. This study aimed to determine sleep quality in patients with chronic burns.

\section{Materials and Methods}

\section{Design and sampling}

This cross-sectional study was conducted on 100 patients referring to the Subspecialty Hospital for Burns 
in Tehran, about 6 months after hospital discharge. The study was conducted over a period of 6 months since December 2013. All patients who met the inclusion criteria and were referred to the hospital after discharge and during a 6 month period, were recruited. The sequential sampling method was used.

The inclusion criteria were history of burns, 6-month interval between their hospitalization and participation in the study, without any neurological and mental problems (as confirmed by their physicians), or taking any tranquilizers and sleep drugs based on self-reports.

\section{Data collection}

The questionnaire used in this research consisted of 2 parts: 1. Demographic part (information about age, marital status, educational level, occupation status, income, burn surface, and the interval between the burns and participation in the study); and 2. Questions about sleep disorders. The Pittsburgh Sleep Quality Index (PSQI) was employed to assess sleep disorders, as well as sleep habits and patterns. The PSQI has 19 items. The index has 4 open-ended questions (e.g. what time did you go to sleep in the last month?) and 15 multiple choice questions (e.g. how was your sleep quality in the last month?). This questionnaire with a sensitivity of $89.6 \%$, has 7 subscales (Backhaus et al. 2002) and investigates the patient's attitude toward sleep quality (sleep habits and sleep patterns) in the past month.

The subscales included: 1 . Subjective sleep quality; 2 . Sleep latency; 3. Sleep duration; 4. Habitual sleep efficiency (based on the ratio of efficient sleep duration to the total time spent in bed); 5. Sleep disturbances (e.g., waking up at night); 6. Use of sleep medications; and 7. Daytime dysfunction. Each subscale is given a score of 0 to $3(0=$ not at all bothered; $1=$ slightly bothered; $2=$ moderately bothered; and $3=$ severely bothered).

The total score for sleep quality, which is the sum of the 7 subscales scores, varies from 0 to 21 , and the total score of 6 or higher indicates a poor sleep quality (Buysse et al. 1989). The reported reliability of the PSQI is $93 \%$ to $98 \%$ (with Cronbach $\alpha=0.8$ and test-retest $=$ 0.87) (Morris, Rohay \& Chasens 2018). After obtaining informed consent from participants and explaining the objectives of the study to them, the required data were collected by self-report. The researcher was present during data collection process to answer the participants' potential questions and to make sure that the questionnaires were thoroughly completed.

\section{Data analysis}

The obtained data were analyzed using SPSS, through calculating frequency and percentage, mean score and Standard Deviation (SD), using the Chi-Square Test. P values less than 0.05 were considered as statistically significant.

\section{Results}

One hundred participants took part in the present study including 50 males and 50 females. The age of the participants ranged between 15 to 45 years, with an average of 27.9 years. Demographic information of the participants is presented in Table 1. The participants' bedtime routines varied from $8 \mathrm{PM}$ to $6 \mathrm{AM}$. In total, $34 \%$ of the participants went to sleep at $11 \mathrm{PM}$ and $22 \%$ of them went to sleep between $1 \mathrm{AM}$ and 4 AM. It took them from 1 minute to 5 hours to fall asleep after going to bed, (Mean \pm SD: 55.4 . Of all patients, $42 \%$ fell asleep 20 minutes after going to bed, and it took about 3 to 5 hours to go to sleep for $4 \%$ of them.

The patients' waking time varied from 3 AM to 4 PM (8.18. In total, $40 \%$ of the participants woke up between $8 \mathrm{AM}$ and $9 \mathrm{AM}$, and $2 \%$ woke up at 4 PM. The sleep duration varied form 4 hours to 13 hours at night (Mean \pm SD: 7.79 . In total, $35 \%$ of the participants were sleeping less than 8 hours per night, and 35\% were sleeping more than 8 hours each night. Only $7 \%$ of the samples were sleeping for 11 to 13 hours each night.

According to the results, $38 \%$ of the participants woke up during the night and $34 \%$ had difficulties with the sleep onset after going to bed, for 3 or more times a week. Because of sleepiness, $30 \%$ of the participants faced problems, like driving in their everyday activities. In addition, $48 \%$ of the participants rated their sleep quality during the past month as either bad or fairly bad (Table 2 ).

Based on the findings, $62 \%$ of the participants did not experience a good sleep quality (Table 3 ). There was a statistically significant relationship between the quality of sleep and $\operatorname{sex}(\mathrm{P}=0.039)$, marital status $(\mathrm{P}=0.003)$, occupation $(\mathrm{P}<0.00)$, level of education $(\mathrm{P}=0.04)$, burn surface $(\mathrm{P}=0.05)$ and time elapsed after burns $(\mathrm{P}=0.028)$. There was neither a statistically significant relationship between age and sleep quality nor between sleep quality and the burn surface (Table 4). 
Table 1. Demographic data of the study participants

\begin{tabular}{|c|c|c|}
\hline Variable & Group & No. (\%) \\
\hline \multirow{2}{*}{ Gender } & Female & $50(50)$ \\
\hline & Male & $50(50)$ \\
\hline \multirow{5}{*}{ Age, (y) } & $15-24$ & $32(32)$ \\
\hline & $25-34$ & $52(52)$ \\
\hline & & \\
\hline & $35-44$ & $8(8)$ \\
\hline & $45-55$ & $6(6)$ \\
\hline \multirow{3}{*}{ Marital status } & Single & $42(42)$ \\
\hline & Married & $46(46)$ \\
\hline & Divorced and widowed & $12(12)$ \\
\hline \multirow{3}{*}{ Educational level } & Illiterate & $14(14)$ \\
\hline & Under high school diploma & $40(40)$ \\
\hline & High school diploma or Higher & $46(46)$ \\
\hline \multirow{5}{*}{ Occupation status } & Self-employed & $26(26)$ \\
\hline & Housewife & $38(38)$ \\
\hline & University student & $14(14)$ \\
\hline & Employee & $8(8)$ \\
\hline & Unemployed & $12(12)$ \\
\hline \multirow{3}{*}{ Income level } & Low & $42(42)$ \\
\hline & Average & $36(36)$ \\
\hline & High & $22(22)$ \\
\hline \multirow{5}{*}{ Burn surface } & Some parts of the body & $42(42)$ \\
\hline & Hands, arms, and trunk & $28(28)$ \\
\hline & Trunk and legs & $8(8)$ \\
\hline & Hand, arms, and face & $18(18)$ \\
\hline & Face & $4(4)$ \\
\hline \multirow{4}{*}{ Time elapsed after bur } & 6 months - 1 year & $30(30)$ \\
\hline & 1 - 2 years & $32(32)$ \\
\hline & 2 - 5 years & $6(6)$ \\
\hline & $>5$ years & $32(32)$ \\
\hline
\end{tabular}


Table 2. Sleep habits of patients in the last month

\begin{tabular}{|c|c|c|c|c|}
\hline \multirow[b]{2}{*}{ Sleep Habits in the Last Month } & \multirow[b]{2}{*}{ None (\%) } & \multicolumn{3}{|c|}{ (\%) } \\
\hline & & $\begin{array}{c}\text { Less Than } \\
\text { Once a Week }\end{array}$ & $\begin{array}{c}\text { Once or Twice } \\
\text { a Week }\end{array}$ & $\begin{array}{l}\text { Three or More } \\
\text { Times a Week }\end{array}$ \\
\hline Cannot fall asleep within 20 minutes & $34(34)$ & $14(14)$ & $18(18)$ & $34(34)$ \\
\hline Wakes up in the middle of the night or early morning & $16(16)$ & $24(24)$ & $22(22$ & $38(38)$ \\
\hline Have to get up to use the bathroom & $24(24)$ & $28(28)$ & $30(30)$ & $18(18)$ \\
\hline Cannot breathe comfortably & $64(64)$ & $12(12)$ & $12(12)$ & $12(12)$ \\
\hline Coughs or snores loudly & $68(68)$ & $8(8)$ & $18(18$ & $22(22)$ \\
\hline Feels too cold & $42(42)$ & $20(20)$ & $16(16)$ & $22(22)$ \\
\hline Feels too hot & $46(46)$ & $24(24)$ & $10(10)$ & $10(10)$ \\
\hline Has bad dreams & $32(32)$ & $30(30)$ & $16(16)$ & $22(225)$ \\
\hline Has pain & $38(38)$ & $20(20)$ & $24(24)$ & $18(18)$ \\
\hline $\begin{array}{l}\text { Other reason(s), please describe, including how } \\
\text { often you have had trouble sleeping }\end{array}$ & 54 (54) & $12(12)$ & 12 (12) & 22 (18) \\
\hline $\begin{array}{l}\text { How often have you taken medicine, in the past } \\
\text { month (prescribed or "over the counter") to help you } \\
\text { sleep? }\end{array}$ & $76(76)$ & $4(4)$ & $6(6)$ & $14(14)$ \\
\hline $\begin{array}{l}\text { How often have you had trouble staying awake while } \\
\text { driving, eating, or engaging in social activities, in the } \\
\text { past month? }\end{array}$ & $76(76)$ & $12(12)$ & $8(8)$ & $4(4)$ \\
\hline $\begin{array}{l}\text { How much of a problem has it been for you to keep } \\
\text { up enough enthusiasm to get things done, in the } \\
\text { past month? }\end{array}$ & $40(40)$ & $18(18)$ & $12(12)$ & $30(30)$ \\
\hline Sleep Quality & Very good & Fairly Good & Fairly Bad & Bad \\
\hline $\begin{array}{c}\text { How would you rate your sleep quality in the past } \\
\text { month overall? }\end{array}$ & $14(4)$ & 12 (12) & $48(48)$ & $26(26)$ \\
\hline
\end{tabular}

\section{Discussion}

Based on the results of the study, more than $50 \%$ of the participants did not have a good sleep quality. This finding was in line with the study by Mayes and associates. The study by Mayes et al. on 22 children suffering from burn, showed that the study patients did not have a good sleep quality and had sleep problems for many years after hospital discharge. Similarly, they also reported that most sleeping disorders were related to overnight awakenings (Mayes et al. 2013). Meanwhile, 74 patient suffering from burn reported sleep disorders a week after hospital discharge (Boeve et al. 2002).

The findings showed that most sleep disorders have been related to nighttime awakenings and difficulty in falling asleep (Boeve et al. 2002). The patients also experienced daily naps and pain during sleep, as well (Boeve et al. 2002). A 36-month longitudinal study conduct-

Table 3. Sleep quality of the participants

\begin{tabular}{ccc}
\hline Sleep Quality & No. (\%) & Mean \pm SD \\
\hline Efficient (PQI score: 0-5) & $38(38)$ & $3.3 \pm 0.9$ \\
\hline Non-efficient (PSQI score: 6-21) & $62(62)$ & $9.96 \pm 3.2$ \\
\hline
\end{tabular}


Table 4. Post discharge sleep quality of burn patients according to their demographic criteria

\begin{tabular}{|c|c|c|c|c|c|}
\hline & \multirow{2}{*}{ Variable } & \multicolumn{3}{|c|}{ Sleep Quality (\%) } & \multirow{2}{*}{$\begin{array}{c}\chi^{2} \text { Test } \\
\mathrm{P}\end{array}$} \\
\hline & & Mean \pm SD & Efficient & Non-Efficient & \\
\hline \multirow{2}{*}{ Sex } & Female & $7.74 \pm 3.4$ & $14(28)$ & $36(72)$ & $\chi^{2}=4.24$ \\
\hline & Male & $6.68 \pm 4.6$ & $24(48)$ & $26(52)$ & $P=0.039$ \\
\hline \multirow{4}{*}{ Age, (y) } & $15-24$ & $6.2 \pm 4.2$ & $16(42.1)$ & $18(29)$ & \multirow{4}{*}{$\begin{aligned} \chi^{2} & =5.00 \\
P & =0.17\end{aligned}$} \\
\hline & $25-34$ & $7.8 \pm 3.7$ & $16(42.1)$ & $36(58.1)$ & \\
\hline & $35-44$ & $9.12 \pm 4.05$ & $2(5.3)$ & $6(9.7)$ & \\
\hline & $45-55$ & $6.16 \pm 4.6$ & $4(10.2)$ & $2(3.2)$ & \\
\hline \multirow{3}{*}{ Marital status } & Single & $6.1 \pm 4.4$ & $24(57.1)$ & $18(42.9)$ & \multirow{3}{*}{$\begin{array}{l}\chi^{2}=12.5 \\
P=0.003\end{array}$} \\
\hline & Married & $8.5 \pm 3.7$ & $12(26.1)$ & $24(73.9)$ & \\
\hline & Divorced and widowed & $6.5 \pm 35$ & $2(16.7)$ & $10(8.3)$ & \\
\hline \multirow{4}{*}{ Education } & Illiterate & $7 \pm 4.2$ & $6(42.9)$ & $8(57.1)$ & \multirow{4}{*}{$\begin{array}{l}\chi^{2}=9.8 \\
P=0.04\end{array}$} \\
\hline & Under high school & $8.27 \pm 4.08$ & $10(25)$ & $30(75)$ & \\
\hline & Diploma & $7.5 \pm 4.5$ & $8(36)$ & $14(63.6)$ & \\
\hline & $\begin{array}{c}\text { High school diploma or } \\
\text { Higher }\end{array}$ & $5.6 \pm 3.04$ & $14(58.3)$ & $10(41.7)$ & \\
\hline \multirow{5}{*}{ Occupation } & Self-employed & $7.7 \pm 4.1$ & $8(28.6)$ & $20(71.4)$ & \multirow{5}{*}{$\begin{array}{l}X^{2}=23.9 \\
P<0.000\end{array}$} \\
\hline & Housewife & $8.3 \pm 3.5$ & $8(21.1)$ & 30 (78.9) & \\
\hline & University student & $3.7 \pm 1.2$ & $12(85.7)$ & $2(14.3)$ & \\
\hline & Employee & $5.1 \pm 2.4$ & $6(75)$ & $2(25)$ & \\
\hline & Unemployed & $8.6 \pm 5.5$ & $4(33.3)$ & $8(66.7)$ & \\
\hline \multirow{3}{*}{ Income level } & Low & $6.92 \pm 3.6$ & $14(36.8)$ & $28(45.2)$ & \multirow{3}{*}{$\begin{aligned} \chi^{2} & =3.27 \\
P & =0.31\end{aligned}$} \\
\hline & Average & $8.00 \pm 4.5$ & $12(31.6)$ & $24(38.7)$ & \\
\hline & High & $6.81 \pm 3.9$ & $12(31.6)$ & $10(16.1)$ & \\
\hline \multirow{6}{*}{ Burn surface } & Majority parts of the body & $7.9 \pm 4.3$ & $6(33)$ & $12(66.7)$ & \multirow{6}{*}{$\begin{array}{l}X^{2}=12.5 \\
P=0.002\end{array}$} \\
\hline & Hands, arms, and trunk & $8.6 \pm 4.5$ & $6(25)$ & $18(75)$ & \\
\hline & Trunk & $3.3 \pm 1.0$ & $6(100)$ & $0(0)$ & \\
\hline & Trunk and legs and hands & $6.4 \pm 3.1$ & $10(33)$ & $20(66.7)$ & \\
\hline & Hand and face & $8.1 \pm 4.3$ & $8(44.4)$ & $10(56.6)$ & \\
\hline & Face & $5.2 \pm 2.6$ & $2(50)$ & $2(50)$ & \\
\hline \multirow{4}{*}{$\begin{array}{l}\text { Time elapsed } \\
\text { after burns }\end{array}$} & 6 months- 1 year & $6.3 \pm 3.7$ & $12(40)$ & $18(60)$ & \multirow{4}{*}{$\begin{array}{c}\chi^{2}=9.1 \\
P=0.028\end{array}$} \\
\hline & 1 - 2 years & $9.3 \pm 4.6$ & $6(18.8)$ & $26(81.3)$ & \\
\hline & $2-5$ years & $5.00 \pm 3.7$ & $4(66.7)$ & $2(33.3)$ & \\
\hline & $>5$ years & $6.3 \pm 2.9$ & $16(50)$ & $16(50)$ & \\
\hline
\end{tabular}


ed by Lee et al. On 142, 19-36 years old adults suffering from burn, reported twice more sleeping disorders in the test subjects, compared to the healthy population.

This study has also reported a relationship between sleep disorders, burn surface and patient's age (Lee et al. 2017). A different finding has been reported by another study on 167 children suffering from severe burn. They reported that the sense of pain, itchiness and sleep disorders have decreased in the studied children. The existence of scar in visible areas also had a relationship with distress of the most children (Wurze et al. 2017). Despite the studies demonstrated in different age groups and various time durations, the similarities in findings indicate sleep disorders in burn patients, following discharge. The difference between the current study findings and Wares study, which has shown sleep disorders decrease throughout the time, could be due to the use of different tools to assess sleep disorders and different methodologies applied in the studies.

Other studies conducted in the acute phase of illness during hospitalization, have shown that these patients also suffered from sleep disorders (Raymond et al. 2001; Summer et al. 2007; Koljonen et al. 2013). The present study showed that burn patients suffer from sleep disorders, even after recovery and hospital discharge. This issue calls for furthur attention from health care providers, because sleep disorders can be a sign of burn patients' inability to cope with their condition.

The findings revealed that a considerable number of burn patients suffered from irregular sleep patterns. About one-third of the participants went to bed after midnight, had sleep latency, and slept less than 8 hours per night. The highest reported sleep disorders included frequent nighttime awakenings, sleep latency, and sleepiness during the day. Boeve et al. In their study with similar findings reported that frequent nighttime awakenings, napping in the daytime, and sleep onset dificulty are common in this group of people (Boeve et al. 2002).

The results indicate that women are more likely to develop sleep disorders in the chronic phase of burn, compared to men. There is no consensus in the literature over this matter. Conducting a study on 150 patients and 50 healthy individuals, Doğan et al. Found a significant relationship between gender and sleep quality. Wasiak et al. Showed that women had a poor quality of life in comparison to men, at 12 months postburn (Wasiak et al. 2017). Contrary to these findings, some studies found that men's sleep quality is not as good as women's sleep quality (Doğan et al. 2005; Frighatto et al. 2004). Utili- zation of various instruments and differnt sample sizees may have resulted in such contradictory findings.

The present study showed a significant relationship between the participants' marital status and their sleep quality. It was found that sleep disorders were more evident in married, widowed, and divorced participants. Sleep problems among divorced and widowed participants may be the result of their stressful life conditions in addition to the burn. The high rate of sleep disorders in married people might be the direct result of the changes that happen in their lives due to burn, like financial pressures resulting from the cost of treatment and the long course of treatment, changes in family relations, and in particular, changes in appearance that could affect relations between husbands and wives suffering from burn (Troxel et al. 2009; Ciofi-Silva et al. 2010). However, further research is necessary in this regard.

According to the results, the participants' sleep quality was significantly associated with their occupational status. A significant number of unemployed individuals and housewives had a poor sleep quality. It could be related to the cost of the treatment process and psychological distress, due to the lack of social activities (Guertler et al. 2015; Van Dyke et al. 2016).

It was found that higher educated people experienced less sleeping problems. This finding supports the results of other studies on sleep disorders (Ohayon 2002; Baur, Hardy \& Van Dorsten 1998). People with higher educational levels seem to be able to cope with their problems more efficiently, and make efforts to overcome their sleep disorders. There was a significant relationship between sleep quality, burn surface and the time elapsed after burn injury. The participants with several burn injuries had poorer sleep quality. Other studies have also shown that the more the burn surface, the higher the chances of sleep disorders would be (Pishnamazi et al. 2012; Liang et al. 2012; Xie et al. 2012).

The limitation of the present study was the small sample size. In addition, further studies are required to identify the risk factors for sleep problems in burn patients. Also, clinical trials are recommended to improve sleep disorder in burn patients. Based on the findings of the present study, most patients had a poor sleep quality. Therefore, we recommend that patients after the discharge seek counseling to help identify and treat their sleep disorders. It is also recommended that health care providers pay close attention to patient's sleep disorders, after the acute burn phase. 


\section{Ethical Considerations}

\section{Compliance with ethical guidelines}

The study was approved by the Ethics Committee of the Research Center of Shahid Motahari Hospital (code: IR.IUMS.REC1394.9311451007). The researcher informed the patients that their future treatment would not be influenced by their consent or refusal to participate in the study, and written consent was obtained from the participants.

\section{Funding}

This research did not receive any specific grant from funding agencies in the public, commercial, or not-forprofit sectors.

\section{Authors contributions}

We, all two authors have contributed significantly to data gathering and the writing and editing of the manuscript, and that all authors are in agreement with its content.

\section{Conflict of interest}

The authors declare no conflict of interest.

\section{Acknowledgements}

We would like to thank all participants to participate in this research.

\section{References}

Asghari, A., et al., 2012. [Severity of depression and anxiety in obstructive sleep apnea syndrome (Persian)]. European Archives of Oto-Rhino-Laryngology, 269(12), pp. 2549-53. [DOI:10.1007/ s00405-012-1942-6] [PMID]

Backhaus, J., et al., 2002. Test-retest reliability and validity of the Pittsburgh Sleep Quality Index in primary insomnia. Journal of Psychosomatic Research, 53(3), pp. 737-40. [DOI:10.1016/S00223999(02)00330-6]

Baur, K. M., Hardy, P. E. \& Van Dorsten, B., 1998. Posttraumatic stress disorder in burn populations: A critical review of the literature. The Journal of Burn Care \& Rehabilitation, 19(3), pp. 230-40. [DOI:10.1097/00004630-199805000-00009]

Bayuo, J., Agbenorku, P. \& Amankwa, R., 2016. Study on acute burn injury survivors and the associated issues. Journal of Acute Disease, 5(3), pp. 206-9. [DOI:10.1016/j.joad.2016.03.006]
Berg, L., et al., 2017. Psychosocial distress at different time intervals after burn injury. Psychotherapie, Psychosomatik, Medizinische Psychologie, 67(6), pp. 231-9. [PMID]

Boeve, S. A., et al., 2002. Sleep disturbance after burn injury. The Journal of Burn Care \& Rehabilitation, 23(1), pp. 32-8. [DOI:10.1097/00004630-200201000-00007]

Buysse, D. J., et al., 1989. The Pittsburgh Sleep Quality Index A new instrument for psychiatric practice and research Psychiatry Research, 28(2), pp. 193-213. [DOI:10.1016/01651781(89)90047-4]

Carter, D. W., Carrougher, G. J. \& Pham, T. N., 2016. Pain management. In D. G. Greenhalgh (eds), Burn Care for General Surgeons and General Practitioners. Berlin: Springer.

Chatburn, A., et al., 2017. The effects of sleep restriction and sleep deprivation in producing false memories. Neurobiology of Learning and Memory, 137, pp. 107-13. [PMID]

Ciofi Silva, C. L., et al., 2010. The life impact of burns: The perspective from burn persons in Brazil during their rehabilitation phase. Disability and Rehabilitation, 32(6), pp. 431-7. [DOI:10.3109/09638280802532555] [PMID]

Cooper, L. N., 2016. Effects of Sleep Fragmentation on the Immune System of Zebra Finches Using Cytokine Gene Expression [MSc. thesis]. Bowling Green, Kentucky: Western Kentucky University.

Cuesta, M., et al., 2016. Simulated night shift disrupts circadian rhythms of immune functions in humans. The Tournal of Immunology, 196(6), pp. 2466-75. [DOI:10.4049/jimmunol.1502422] [PMID]

Devita, M., et al., 2017. Obstructive sleep apnea and its controversial effects on cognition. Journal of Clinical and Experimental Neuropsychology, 39(7), pp. 659-69.

Doğan, O., Ertekin, S. \& Doğan, S., 2005. Sleep quality in hospitalized patients. Journal of Clinical Nursing, 14(1), pp. 107-13. [DOI:10.1111/j.1365-2702.2004.01011.x] [PMID]

Frighetto, L., et al., 2004. An assessment of quality of sleep and the use of drugs with sedating properties in hospitalized adult patients. Health and Quality of Life Outcomes, 2(1), p. 17

Gauffin, E., et al., 2016. Health-related Quality of life (EQ-5D) early after injury predicts long-term pain after burn. Burns, 42(8), pp. 1781-8.

Giannoni-Pastor, A., et al., 2016. Prevalence and predictors of posttraumatic stress symptomatology among burn survivors: A systematic review and meta-analysis. Journal of Burn Care \& Research, 37(1), pp. e79-e89. [DOI:10.1097/ BCR.0000000000000226] [PMID]

Grandner, M. A., et al., 2012. Sleep disturbance is associated with cardiovascular and metabolic disorders. Journal of Sleep Research, 21(4), pp. 427-33. [DOI:10.1111/j.13652869.2011.00990.x] [PMID] [PMCID]

Guertler, D., et al., 2015. The association between physical activity, sitting time, sleep duration, and sleep quality as correlates of presenteeism. Journal of Occupational and Environmental Medicine, 57(3), pp. 321-8. [DOI:10.1097/JOM.0000000000000355] [PMID] [PMCID]

Itani, O., et al., 2017. Short sleep duration and health outcomes: A systematic review, meta-analysis, and meta-regression. Sleep Medicine, 32, pp. 246-56. [DOI:10.1016/j.sleep.2016.08.006] 
Jeddi, S., et al., 2016. The effect of sleep deprivation on cardiac function and tolerance to ischemia-reperfusion injury in male rats. $A r-$ quivos Brasileiros de Cardiologia, 106(1), pp. 41-8. [PMID] [PMCID]

Kendzerska, T., et al., 2014. Obstructive sleep apnea and risk of cardiovascular events and all-cause mortality: A decadelong historical cohort study. PLoS Medicine, 11(2), p. e1001599. [DOI:10.1371/journal.pmed.1001599]

Kheyri, A., Bastani, F. \& Haghani, H., 2016. Effects of reflexology on sleep quality of elderly women undergoing abdominal surgery. Journal of Client-Centered Nursing Care, 2, 11-18.

Kim, S. Y., et al., 2015. Sleep deprivation is associated with bicycle accidents and slip and fall injuries in Korean adolescents. PLoS One, 10(8), p. e0135753. [DOI:10.1371/journal. pone.0135753] [PMID] [PMCID]

Koljonen, V., et al., 2013. Treatment of patients with severe burns-costs and health-related quality of life outcome. Journal of Burn Care \& Research, 34(6), pp. e318-25. [DOI:10.1097/ BCR.0b013e3182779c90] [PMID]

Lee, A. F., et al., 2017. Quantifying risk factors for long-term sleep problems after burn injury in young adults. Journal of Burn Care \& Research, 38, e510-e520.

Legault, G., et al., 2017. Cognitive consequences of sleep deprivation, shiftwork, and heat exposure for underground miners. Applied Ergonomics, 58, pp. 144-50. [DOI:10.1016/j.apergo.2016.06.007] [PMID]

Liang, C. Y., et al., 2012. Predictors of health-care needs in discharged burn patients. Burns, 38(2), pp. 172-9. [DOI:10.1016/j. burns.2011.09.010] [PMID]

Metlaine, A., Leger, D. \& Choudat, D., 2005. Socioeconomic impact of insomnia in working populations. Industrial Health, 43, pp. 11-19.

Mayes, T., et al., 2013. A pilot review of the long-term impact of burn injury on sleep architecture in children. Journal of Burn Care \& Research, 34, e15-e21.

Marin, J. M., et al., 2012. Association between treated and untreated obstructive sleep apnea and risk of hypertension. The Latest Medical Research, Reviews, and Guidelines, 307(20), pp. 2169-76. [DOI:10.1001/jama.2012.3418] [PMID] [PMCID]

Matheson, J., Clayton, J. \& Muller, M., 2001. The reduction of itch during burn wound healing. Journal of Burn Care $\mathcal{E}$ Research, 22(1), pp. 76-81. [DOI:10.1097/00004630-200101000-00017]

Mcneil, J., et al., 2016. The effects of partial sleep restriction and altered sleep timing on appetite and food reward. Appetite, 109, pp. 48-56. [DOI:10.1016/j.appet.2016.11.020] [PMID]

Morris, J. L., Rohay, J. \& Chasens, E. R., 2018. Sex differences in the psychometric properties of the Pittsburgh sleep quality index. Journal of Women's Health, 27(3), pp. 278-82. [DOI:10.1089/ jwh.2017.6447] [PMID]

Ohayon, M. M., 2002. Epidemiology of insomnia: What we know and what we still need to learn. Sleep Medicine Reviews, 6(2), pp. 97-111. [DOI:10.1053/smrv.2002.0186] [PMID]

Ohayon, M. M., 2005. Relationship between chronic painful physical condition and insomnia. Journal of Psychiatric Research, 39(2), pp. 151-9. [DOI:10.1016/j.jpsychires.2004.07.001] [PMID]
Ohayon, M. M., Reynolds III, C. F. \& Dauvilliers, Y., 2013. Excessive sleep duration and quality of life. Annals of Neurology, 73(6), pp. 785-94. [DOI:10.1002/ana.23818] [PMID] [PMCID]

Peppard, P. E., et al., 2000. Prospective study of the association between sleep-disordered breathing and hypertension. New England Journal of Medicine, 342(19), pp. 1378-84. [DOI:10.1056/ NEJM200005113421901] [PMID]

Pishnamazi, Z., et al., 2012. Quality of life in burn patients. Payesh Journal, 11(1), pp. 103-10.

Polak, J., Beamer, B. A. \& Punjabi, N. M., 2016. Obstructive sleep apnea and glucose metabolism. In: A. I. Pack (eds), Sleep Apnea: Pathogenesis, Diagnosis and Treatment. London: Informa.

Raymond, I., et al., 2001. Quality of sleep and its daily relationship to pain intensity in hospitalized adult burn patients. Pain, 92(3), pp. 381-8. [DOI:10.1016/S0304-3959(01)00282-2]

Reimer, M. A. \& Flemons, W. W., 2003. Quality of life in sleep disorders. Sleep Medicine Reviews, 7(4), pp. 335-349. [DOI:10.1053/ smrv.2001.0220] [PMID]

Richardson, P. \& Mustard, L., 2009. The management of pain in the burns unit. Burns, 35(7), pp. 921-36. [DOI:10.1016/j. burns.2009.03.003] [PMID]

Seyyed-Rasooli, A., et al., 2016. Comparing the effects of aromatherapy massage and inhalation aromatherapy on anxiety and pain in burn patients: A single-blind randomized clinical trial. Burns, 42(8), pp. 1774-80. [DOI:10.1016/j.burns.2016.06.014] [PMID]

Shanahan, L., et al., 2014. Sleep problems predict and are predicted by generalized anxiety/depression and oppositional defiant disorder. Journal of the American Academy of Child $\mathcal{E}$ Adolescent Psychiatry, 53(5), pp. 550-8. [DOI:10.1016/j. jaac.2013.12.029] [PMID] [PMCID]

Smith, M. T., et al., 2008. Sleep onset insomnia symptoms during hospitalization for major burn injury predict chronic pain. Pain, 138(3), pp. 497-506. [DOI:10.1016/j.pain.2008.01.028] [PMID] [PMCID]

Summer, G. J., et al., 2007. Burn injury pain: The continuing challenge. The Journal of Pain, 8(7), pp. 533-48. [DOI:10.1016/j. jpain.2007.02.426] [PMID]

Tang, N. K., et al., 2014. Impact of musculoskeletal pain on insomnia onset: A prospective cohort study. Rheumatology, 54(2), pp. 248-56. [DOI:10.1093/rheumatology/keu283]

Troxel, W. M., et al., 2009. Marital happiness and sleep disturbances in a multi-ethnic sample of middle-aged women. Behavioral Sleep Medicine, 7(1), pp. 2-19. [DOI:10.1080/15402000802577736] [PMID] [PMCID]

Van der Does, A. J. W., 1989. Patients' and nurses' ratings of pain and anxiety during burn wound care. Pain, 39(1), pp. 95-101. [DOI:10.1016/0304-3959(89)90179-6]

Van Dyke, M. E., et al., 2016. Socioeconomic status discrimination is associated with poor sleep in African-Americans, but not Whites. Social Science \& Medicine, 153, pp. 141-7. [DOI:10.1016/j.socscimed.2016.02.012] [PMID] [PMCID]

Vetrichevvel, T. P., et al., 2016. Burn injury and long-term nervous system morbidity: A population-based cohort study. BMJ Open, 6(9), p. e012668. [DOI:10.1136/bmjopen-2016-012668] 
Wasiak, J., et al., 2017. Female patients display poorer burn-specific quality of life 12 months after a burn injury. Injury, 48(1) pp. 87-93. [PMID]

Wheaton, A. G., 2016. Sleep duration and injury-related risk behaviors among high school students - United States, 20072013. Morbidity and Mortality Weekly Report, 65(13), pp. 337-41. [DOI:10.15585/mmwr.mm6513a1] [PMID]

Wiechman, S., Kalpakjian, C. Z. \& Johnson, K. L., 2016. Measuring depression in adults with burn injury: A systematic review. Journal of Burn Care \& Research, 37(5), pp. e415-26. [DOI:10.1097/BCR.0000000000000384] [PMID]

Wurzer, P., et al., 2017. Two-year follow-up of outcomes related to scarring and distress in children with severe burns. Disability and rehabilitation, 39, 1639-43.

Xie, B., et al., 2012. Evaluation of long term health-related quality of life in extensive burns: A 12-year experience in a burn center. Burns, 38(3), pp. 348-55. [DOI:10.1016/j.burns.2011.09.003]

Yangzom, N., et al., 2015. The effect of diphenhydramine on sleep in pediatric burn patients: A secondary analysis. Journal of Burn Care E Research, 36(2), pp. 266-71. [DOI:10.1097/ BCR.0000000000000066] [PMID]

Yarnell, A. M. \& Deuster, P., 2016. Sleep As A Strategy For Optimizing Performance. Special Operations Medical Journal, 16(1), pp. 81-5. [PMID] 